Article

\title{
Recognition of $\mathrm{V}^{3+} / \mathrm{V}^{4+} / \mathrm{V}^{5+}$ Multielectron Reactions in $\mathrm{Na}_{3} \mathrm{~V}\left(\mathrm{PO}_{4}\right)_{2}$ : A Potential High Energy Density Cathode for Sodium-Ion Batteries
}

\author{
Rui Liu ${ }^{1,2} \mathbb{D}$, Ziteng Liang ${ }^{2}$, Yuxuan Xiang ${ }^{2}$, Weimin Zhao ${ }^{3}$, Haodong Liu 4 , ${ }^{*}$, Yan Chen ${ }^{5}$, \\ Ke An ${ }^{5}$ and Yong Yang ${ }^{2,6, *}$ \\ 1 School of Materials Science and Engineering, Shandong University of Science and Technology, \\ Qingdao 266590, China; liurui@sdust.edu.cn \\ 2 Collaborative Innovation Center of Chemistry for Energy Materials, State Key Laboratory for Physical \\ Chemistry of Solid Surface, Department of Chemistry, College of Chemistry and Chemical Engineering, \\ Xiamen University, Xiamen 361005, China; ziteng_liang@163.com (Z.L.); nuaaxyx@163.com (Y.X.) \\ 3 College of Chemical Engineering and Safety, Binzhou University, Binzhou 256603, China; \\ zhaoweimin137@sina.com \\ 4 Department of NanoEngineering, University of California San Diego, 9500 Gilman Drive, \\ La Jolla, CA 92093, USA \\ 5 Neutron Scattering Division, Oak Ridge National Laboratory, Oak Ridge, TN 37830, USA; \\ cheny1@ornl.gov (Y.C.); kean@ornl.gov (K.A.) \\ 6 School of Energy Research, Xiamen University, Xiamen 361005, China \\ * Correspondence: haodong.liu.xmu@gmail.com (H.L.); yyang@xmu.edu.cn (Y.Y.); \\ Tel.: +1-858-999-4944 (H.L.); +86-592-2185753 (Y.Y.)
}

Academic Editor: Gregorio F. Ortiz

Received: 24 January 2020; Accepted: 21 February 2020; Published: 24 February 2020

\begin{abstract}
Na}_{3} \mathrm{~V}\left(\mathrm{PO}_{4}\right)_{2}$ was reported recently as a novel cathode material with high theoretical energy density for Sodium-ion batteries (SIBs). However, whether $\mathrm{V}^{3+} / \mathrm{V}^{4+} / \mathrm{V}^{5+}$ multielectron reactions can be realized during the charging process is still an open question. In this work, $\mathrm{Na}_{3} \mathrm{~V}\left(\mathrm{PO}_{4}\right)_{2}$ is synthesized by using a solid-state method. Its atomic composition and crystal structure are verified by X-ray diffraction (XRD) and neutron diffraction (ND) joint refinement. The electrochemical performance of $\mathrm{Na}_{3} \mathrm{~V}\left(\mathrm{PO}_{4}\right)_{2}$ is evaluated in two different voltage windows, namely 2.5-3.8 and 2.5-4.3 V. ${ }^{51} \mathrm{~V}$ solid-state NMR (ssNMR) results disclose the presence of $\mathrm{V}^{5+}$ in $\mathrm{Na}_{2-x} \mathrm{~V}\left(\mathrm{PO}_{4}\right)_{2}$ when charging $\mathrm{Na}_{3} \mathrm{~V}\left(\mathrm{PO}_{4}\right)_{2}$ to $4.3 \mathrm{~V}$, confirming $\mathrm{Na}_{3} \mathrm{~V}\left(\mathrm{PO}_{4}\right)_{2}$ is a potential high energy density cathode through realization of $\mathrm{V}^{3+} / \mathrm{V}^{4+} / \mathrm{V}^{5+}$ multielectron reactions.
\end{abstract}

Keywords: polyanion; energy density; multielectron reaction; solid-state NMR

\section{Introduction}

Large-scale energy storage systems (ESSs) that are used in renewable solar and wind energy systems and smart grids have received great attention due to increasing energy demands [1-3]. The low cost and inexhaustible and ubiquitous sodium resources make Sodium-ion batteries (SIBs) an attractive and promising candidate for ESSs $[3,4]$. In this case, many types of compounds including layered oxides [5-7], polyanionic frameworks [8-11] and hexacyanoferrates [12-14] have been explored as cathode materials for SIBs. Among them, polyanion-based compounds have attracted extensive interest due to their excellent cycling stability, high safety, and adjustable voltage [8-10]. However, the specific capacity and energy density of polyanion-based compounds are generally lower than the layered transition metal oxides $[15,16]$. More specifically, the energy density of polyanion-type materials is usually lower than $500 \mathrm{Wh} / \mathrm{kg}$ [15]. 
Recently we have reviewed the progress of multielectron reactions in polyanionic materials and concluded that exploring multielectron reactions in polyanionic cathodes could substantially improve the energy density by increasing both the reacting electron number and the voltage of cathodes according to Equation (1) [17]:

$$
\begin{gathered}
E=Q V \\
=26800 \frac{n V}{M}(\mathrm{Wh} / \mathrm{kg})
\end{gathered}
$$

where $Q$ is the specific capacity, $V$ is the voltage vs. $\mathrm{Na}^{+} / \mathrm{Na}$ in this work, $n$ is the number of electrons involved in the reaction, and $M$ is the molecular weight of the material. We have further proposed that $\mathrm{V}^{3+} / \mathrm{V}^{4+} / \mathrm{V}^{5+}$ and $\mathrm{Mn}^{2+} / \mathrm{Mn}^{3+} / \mathrm{Mn}^{4+}$ redox couples are readily accessible in many polyanionic cathodes.

Figure 1 shows polyanion-type cathodes with multielectron reactions which are plotted on the basis of Table S1 [18-27]. Among them, the well-known NASICON (Na superionic conductors)-type $\mathrm{Na}_{3} \mathrm{~V}_{2}\left(\mathrm{PO}_{4}\right)_{3}$ exhibits one $\mathrm{V}^{3+} / \mathrm{V}^{4+}$ redox couple at $3.4 \mathrm{~V}$ due to two $\mathrm{Na}$ (in the $\mathrm{Na}(2)$ site) extraction while the third $\mathrm{Na}$ in the $\mathrm{Na}(1)$ site could not be extracted in a common voltage range [28-30]. Consequently, a V/M $M^{3+}\left(M^{3+}=\mathrm{Fe}^{3+}[31], \mathrm{Al}^{3+}[26,32], \mathrm{Cr}^{3+}\right.$ [25,33], etc.) replacement could improve the energy density of $\mathrm{Na}_{3} \mathrm{~V}_{2}\left(\mathrm{PO}_{4}\right)_{3}$-based cathodes by introducing a high voltage plateau $(\sim 4.1 \mathrm{~V})$ through the activation of a $\mathrm{V}^{4+} / \mathrm{V}^{5+}$ reaction. Our recent work has testified to the reversible $\mathrm{V}^{3+} / \mathrm{V}^{4+} / \mathrm{V}^{5+}$ reactions through ex situ X-ray absorption near edge structure (XANES) and ${ }^{51}$ V solid-state NMR (ssNMR) [25]. In addition, Goodenough et al. reported that reversible $\mathrm{Mn}^{2+} / \mathrm{Mn}^{3+} / \mathrm{Mn}^{4+}$ reactions could also be accessed in $\mathrm{Na}_{3} \mathrm{MnM}\left(\mathrm{PO}_{4}\right)_{3}\left(\mathrm{M}^{4+}=\mathrm{Ti}^{4+}\right.$ [23], $\mathrm{Zr}^{4+}$ [24], etc.) and thus show slightly enhanced energy density compared to the $\mathrm{Na}_{3} \mathrm{~V}_{2}\left(\mathrm{PO}_{4}\right)_{3}$. The multielectron reactions in $\mathrm{Na}_{3} \mathrm{MnM}\left(\mathrm{PO}_{4}\right)_{3}$ are proved by $X$-ray photoelectron spectroscopy (XPS) at different states of charge [24]. However, the energy density of the above-mentioned cathodes is not improved much. Recently, V/M ${ }^{2+}\left(\mathrm{Fe}^{2+}[18], \mathrm{Mn}^{2+}[19,20]\right.$, etc.) substitution was proven to improve the energy density of $\mathrm{Na}_{4} \mathrm{VM}\left(\mathrm{PO}_{4}\right)_{3}$ up to higher than $500 \mathrm{Wh} / \mathrm{kg}$ by introducing excess $\mathrm{Na}$ and new redox couples $\left(\mathrm{Fe}^{2+} \mathrm{Fe} /{ }^{3+}\right.$ or $\left.\mathrm{Mn}^{2+} / \mathrm{Mn}^{3+} / \mathrm{Mn}^{4+}\right)$ in addition to $\mathrm{V}^{3+} / \mathrm{V}^{4+} / \mathrm{V}^{5+}$ reactions. Unfortunately, they exhibit quick capacity loss and high structural irreversibility. Other than NASICON-type cathodes, $\mathrm{Na}_{3} \mathrm{~V}_{2}\left(\mathrm{PO}_{4}\right)_{2} \mathrm{~F}_{3}$ shows an energy density of $\sim 506 \mathrm{Wh} / \mathrm{kg}$ with two $\mathrm{Na}$ extraction and the oxidation of $\mathrm{V}^{3+}$ to $\mathrm{V}^{4+}$ below $4.3 \mathrm{~V}[34,35]$. Very recently, Tarascon et al. reported that the third $\mathrm{Na}$ in $\mathrm{Na}_{3} \mathrm{~V}_{2}\left(\mathrm{PO}_{4}\right)_{2} \mathrm{~F}_{3}$ can be extracted at $\sim 4.7 \mathrm{~V}$, thus resulting in a high theoretical energy density of $810 \mathrm{Wh} / \mathrm{kg}[21,22]$.

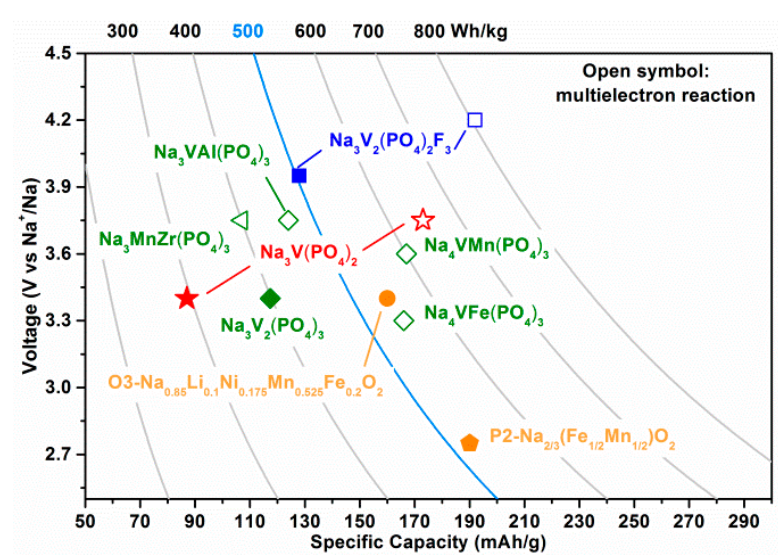

Figure 1. Operation voltages versus specific capacities of cathode materials for sodium-ion batteries.

$\mathrm{Na}_{3} \mathrm{~V}\left(\mathrm{PO}_{4}\right)_{2}$ was recently reported as a novel cathode material with a theoretical capacity of $173 \mathrm{mAh} / \mathrm{g}$ and two voltage plateaus at ca. 3.6 and $4.0 \mathrm{~V}$, leading to a theoretical energy density of $657 \mathrm{Wh} / \mathrm{kg}[36,37]$. The low-voltage plateau can be ascribed to the oxidation of $\mathrm{V}^{3+}$ to $\mathrm{V}^{4+}$ on the basis of V K-edge XANES spectra, which corresponds to one Na extraction [37]. However, the high-voltage plateau only shows in the first charge while disappeared in the following charge/discharge process. Moreover, only small changes are observed in this region from in situ XRD patterns, thus possible 
electrolyte decomposition cannot be ruled out [36]. Consequently, whether this $4.0 \mathrm{~V}$ plateau is ascribed to a $\mathrm{V}^{4+} / \mathrm{V}^{5+}$ reaction remains an open question.

${ }^{51} \mathrm{~V}$ ssNMR is a reliable method to ensure the presence of $\mathrm{V}^{5+}$, because only signals of $\mathrm{V}^{5+}$ compounds without localized $d$ electron are visible when using standard NMR methods [25,35,38]. For instance, Croguennec et al. revealed a charge disproportionation of two $\mathrm{V}^{4+}$ ions into $\mathrm{V}^{3+}$ and $\mathrm{V}^{5+}$ occurs in $\mathrm{NaV}_{2}\left(\mathrm{PO}_{4}\right)_{2} \mathrm{~F}_{3}$ by using ${ }^{51} \mathrm{~V}$ ssNMR, which confirmed the presence of $\mathrm{V}^{5+}$ in $\mathrm{NaV}_{2}\left(\mathrm{PO}_{4}\right)_{2} \mathrm{~F}_{3}$ [35]. As mentioned above, we have also recognized $\mathrm{V}^{5+}$ in $\mathrm{Na}_{2-x} \mathrm{VCr}\left(\mathrm{PO}_{4}\right)_{3}$ through ${ }^{51} \mathrm{~V}$ ssNMR and further disclosed the $\mathrm{V}^{3+} / \mathrm{V}^{4+} / \mathrm{V}^{5+}$ multielectron reactions [25]. In this work, we revealed the presence of $\mathrm{V}^{5+}$ in $\mathrm{Na}_{2-x} \mathrm{~V}\left(\mathrm{PO}_{4}\right)_{2}$ through ${ }^{51} \mathrm{~V}$ ssNMR. This is conclusive evidence that $\mathrm{Na}_{3} \mathrm{~V}\left(\mathrm{PO}_{4}\right)_{2}$ is a potential high energy cathode with a high theoretical energy density of $657 \mathrm{Wh} / \mathrm{kg}$.

\section{Results}

Recently, Kang and Masquelier et al. have obtained $\mathrm{Na}_{3} \mathrm{~V}\left(\mathrm{PO}_{4}\right)_{2}$ almost at the same time. The crystal structure consists of a $\mathrm{C} 2 / \mathrm{c}$ symmetry with a monoclinic system according to single crystal $\mathrm{XRD}[36,37]$. Here we synthesized $\mathrm{Na}_{3} \mathrm{~V}\left(\mathrm{PO}_{4}\right)_{2} / \mathrm{C}$ using a solid-state method and the atomic ratio of $\mathrm{Na}: \mathrm{P}$ and V:P is determined to be 1.50 and 0.53 using inductively coupled plasma (ICP), respectively, which fits well with their theoretical values. Moreover, the structure of the product was further analyzed by XRD and neutron diffraction (ND). The combined Rietveld XRD and ND were carried out using the monoclinic structural model reported in [36,37], as shown in Figure 2. The structure of $\mathrm{Na}_{3} \mathrm{~V}\left(\mathrm{PO}_{4}\right)_{2}$ is a C2/c symmetry with cell parameters of $a=9.09149(16) \AA, b=5.03480(10) \AA, c=13.86207(20) \AA$, $\beta=91.2456(16)$, and $V=634.37 \AA^{3}$, which is in good agreement with the literature [36,37]. The detailed structure information is summarized in Table S2. Part of the bond length and angle were calculated based the obtained structure and listed in Table S3. It is worth to note, that the V-O bond length and $\mathrm{P}-\mathrm{O}$ bond length fit well with the reported $\mathrm{VO}_{6}$ and $\mathrm{PO}_{4}$ results, respectively [11].
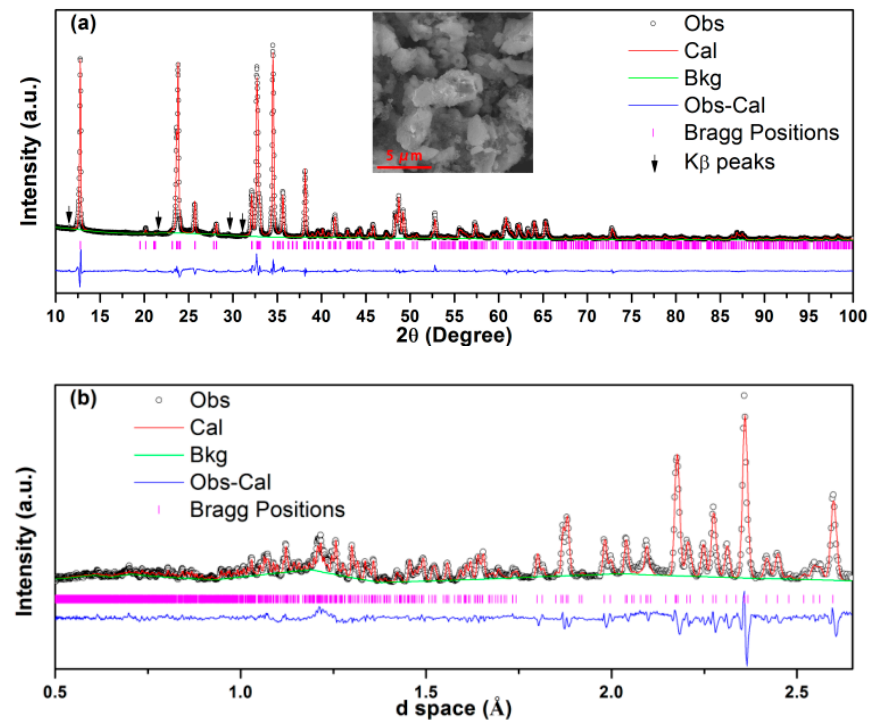

Figure 2. Combined Rietveld refinement of the (a) $\mathrm{XRD}\left(\mathrm{R}_{\mathrm{wp}}=8.04 \%, \mathrm{R}_{\mathrm{p}}=6.20 \%\right)$ and (b) neutron diffraction (ND) $\left(\mathrm{R}_{\mathrm{wp}}=6.82 \%, \mathrm{R}_{\mathrm{p}}=5.39 \%\right)$ patterns of $\mathrm{Na}_{3} \mathrm{~V}\left(\mathrm{PO}_{4}\right)_{2}$. Arrows in the XRD pattern indicate residual $\mathrm{Cu} \mathrm{K} \mathrm{K}_{\beta}$ peaks caused by the diffractometer. The overall $\mathrm{R}_{\mathrm{wp}}$ and $\mathrm{R}_{\mathrm{p}}$ are $7.45 \%$ and $5.73 \%$, respectively.

Figure 3 shows the schematic crystal structure of $\mathrm{Na}_{3} \mathrm{~V}\left(\mathrm{PO}_{4}\right)_{2}$ based on the obtained structural information. The framework of $\mathrm{Na}_{3} \mathrm{~V}\left(\mathrm{PO}_{4}\right)_{2}$ is built from $\mathrm{VO}_{6}$ octahedra and $\mathrm{PO}_{4}$ tetrahedra units, as shown in Figure 3a. Each $\mathrm{VO}_{6}$ octahedra connects with six $\mathrm{PO}_{4}$ tetrahedra and each $\mathrm{PO}_{4}$ tetrahedra connects to three $\mathrm{VO}_{6}$ octahedra, all in a corner-sharing mode, to form $\left[\mathrm{V}_{5}\left(\mathrm{PO}_{4}\right)_{6}\right]$ units. It is worth noting that one oxygen atom $(\mathrm{O} 1)$ in the $\mathrm{PO}_{4}$ tetrahedra does not attach to the $\mathrm{VO}_{6}$ octahedra, as shown 
Figure $3 b$. Overall, the $\left[\mathrm{V}_{5}\left(\mathrm{PO}_{4}\right)_{6}\right]$ units are interconnected to form infinite slabs of $\left[\mathrm{V}_{2}\left(\mathrm{PO}_{4}\right)_{4}\right]_{\infty}$ in the $a b$ plane and further stack along the $c$ direction to form a layered $\mathrm{V}\left(\mathrm{PO}_{4}\right)_{2}$ framework. There are two different oxygen environment interstitial sites in the layered $\mathrm{V}\left(\mathrm{PO}_{4}\right)_{2}$ framework: Na1 with six fold coordination and $\mathrm{Na} 2$ with eight fold coordination. $\mathrm{Na} 1$ and $\mathrm{Na} 2$ construct $\mathrm{Na}$ layers, which stack with $\mathrm{V}\left(\mathrm{PO}_{4}\right)_{2}$ layers alternatively along the $c$ direction to form the crystal, as can be seen in Figure 3c. Figure S1 (Supplementary Materials) further demonstrates that Na1 and Na2 locate in line with V and $\mathrm{P}$ atoms along the $c$ axis, respectively. Moreover, the bond valence sum (BVS) map shown in Figure 3d,e implies an evident 2D diffusion pathway of $\mathrm{Na}^{+}$in the structure [39].
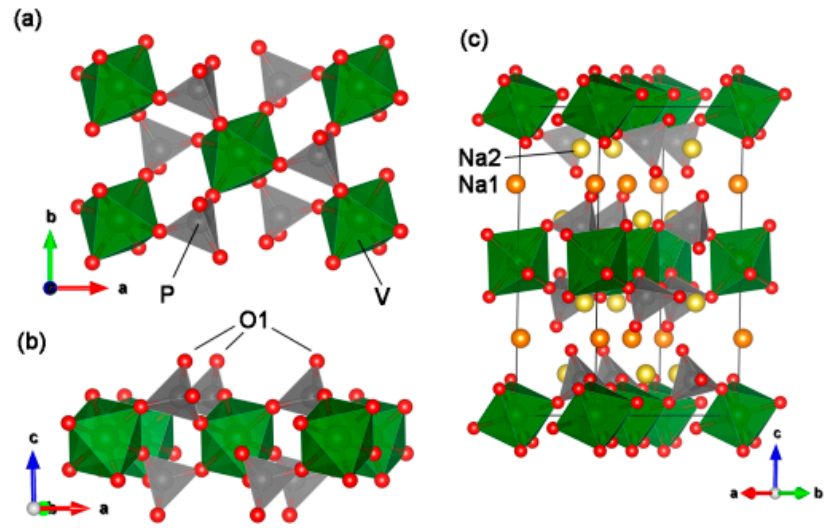

(d)
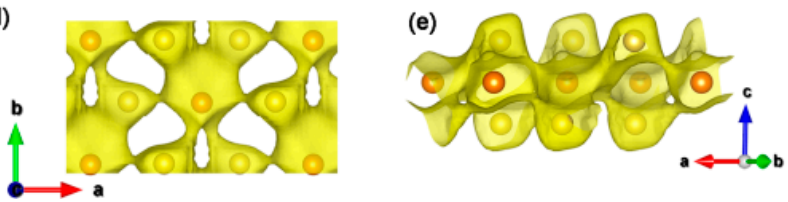

Figure 3. $(\mathbf{a}-\mathbf{c})$ Structural illustration and (d,e) BVS map of layered $\mathrm{Na}_{3} \mathrm{~V}\left(\mathrm{PO}_{4}\right)_{2}$.

The inserted SEM image in Figure 2a and Figure S2 shows that the shape of the product is irregular with the particle size from several to tens of micrometers. Figure $\mathrm{S} 3$ shows nearly the same XANES edge position and pre-edge features of $\mathrm{Na}_{3} \mathrm{~V}\left(\mathrm{PO}_{4}\right)_{2}$ and $\mathrm{Na}_{3} \mathrm{VCr}\left(\mathrm{PO}_{4}\right)_{3}$, in which the valance of the vanadium ion is +3 , indicating that the oxidation state of the vanadium ion in $\mathrm{Na}_{3} \mathrm{~V}\left(\mathrm{PO}_{4}\right)_{2}$ is +3 [25].

The electrochemical performances of $\mathrm{Na}_{3} \mathrm{~V}\left(\mathrm{PO}_{4}\right)_{2}$ as a $\mathrm{Na}$ insertion host compound were evaluated by cyclic voltammetry $(\mathrm{CV})$ at a scan rate of $0.05 \mathrm{mV} / \mathrm{s}$, as shown in Figure 4. The major CV features are the one anodic peak and two cathodic peaks during the first cycle in the voltage range of 2.5-3.8 V when tested at $30^{\circ} \mathrm{C}$. The anode peak shifts slightly toward a lower voltage in the second cycle and then keeps at the same position in the third cycle, meaning a good stability of the structure during $\mathrm{Na}$ (de)insertion. Besides, it is noted that the anodic peaks should be composited of two peaks according to the asymmetric feature. Indeed, the anodic peak splits into two peaks at $45^{\circ} \mathrm{C}$, indicating the sluggish kinetics of the low-voltage reaction. The quasi-open circuit voltage (QOCV) curve in Figure S4 further shows the sluggish kinetics of the low-voltage reaction. Masquelier et al. have also observed this phenomenon [36]. An additional anodic peak at $\sim 4.1 \mathrm{~V}$ is observed from the CV curve when extending the voltage from 3.8 to $4.5 \mathrm{~V}$, as shown in Figure $4 \mathrm{~b}$, implying another redox couple is activated. However, the extended voltage range results in inferior reversibility, as indicated by the decreased intensities of the anodic and cathodic peaks.

Figure $4 \mathrm{c}$ displays galvanostatic charge/discharge profiles in the voltage range of $2.5-3.8 \mathrm{~V}$ at rates of $\mathrm{C} / 20$. Notably, a capacity of $82.6 \mathrm{mAh} / \mathrm{g}$ can be obtained in the first charge with a relatively flat voltage plateau at ca. $3.56 \mathrm{~V}$ vs. $\mathrm{Na}^{+} / \mathrm{Na}$, which is almost equal to $1 \mathrm{Na}$ deinsertion. The discharge curve shows two plateaus at 3.51 and $3.31 \mathrm{~V}$, resulting in a capacity of $67.3 \mathrm{mAh} / \mathrm{g}$, corresponding to an initial coulombic efficiency of $81.5 \%$. Furthermore, two plateaus can be seen from the charge curve in the following cycles, which is consistent with the $\mathrm{CV}$ results. An additional voltage plateau at $\sim 4.1 \mathrm{~V}$ can be seen once the cut-off voltage becomes $4.3 \mathrm{~V}$, as shown in Figure $4 \mathrm{~d}$. The charge capacity is 102.4 
$\mathrm{mAh} / \mathrm{g}$, corresponding to a $1.2 \mathrm{Na}$ deinsertion. Unfortunately, the discharge capacity is $71.4 \mathrm{mAh} / \mathrm{g}$, which is only slightly higher than the discharge capacity of $\mathrm{Na}_{3} \mathrm{~V}\left(\mathrm{PO}_{4}\right)_{2}$ with a narrower voltage window. Moreover, from Figure S5 we conclude that the capacity of $\mathrm{Na}_{3} \mathrm{~V}\left(\mathrm{PO}_{4}\right)_{2}$ drops faster in the voltage window of $2.5-4.3 \mathrm{~V}$ than $2.5-3.8 \mathrm{~V}$.
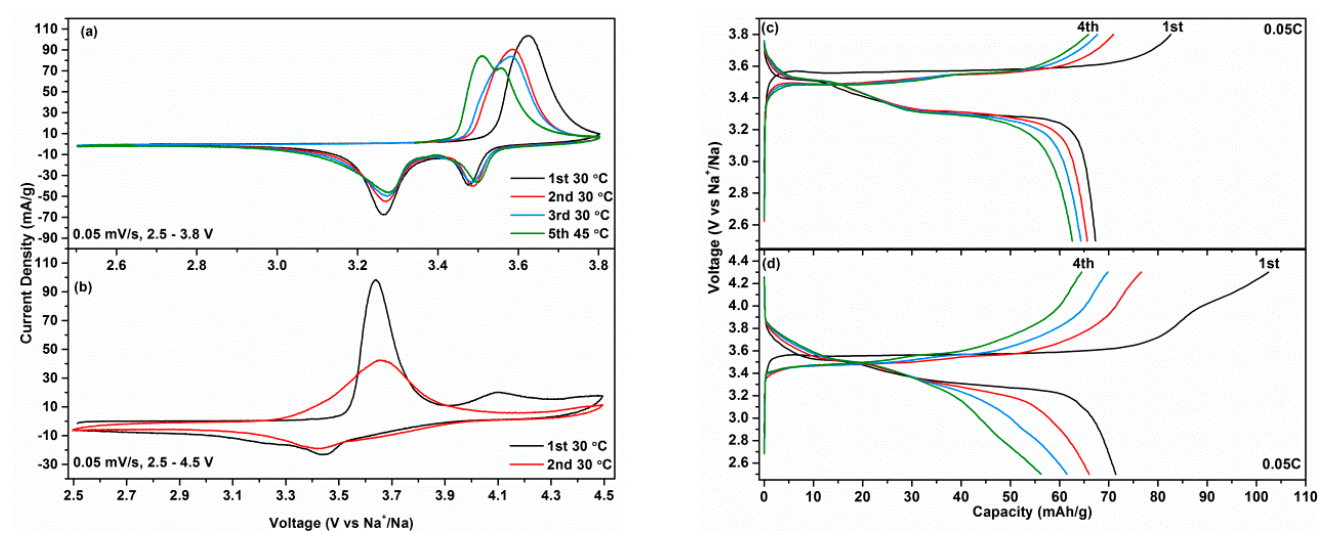

Figure 4. Cyclic voltammetry (CV) $(\mathbf{a}, \mathbf{b})$ and charge/discharge $(\mathbf{c}, \mathbf{d})$ curves of the $\mathrm{Na}_{3} \mathrm{~V}\left(\mathrm{PO}_{4}\right)_{2}$ cathode.

Ex situ ${ }^{51} \mathrm{~V}$ ssNMR was carried out to recognize $\mathrm{V}^{5+}$ in $\mathrm{Na}_{2-x} \mathrm{~V}\left(\mathrm{PO}_{4}\right)_{2}$ for testifying $\mathrm{V}^{3+} / \mathrm{V}^{4+} / \mathrm{V}^{5+}$ multielectron reactions of $\mathrm{Na}_{3} \mathrm{~V}\left(\mathrm{PO}_{4}\right)_{2}$ when charging to $4.3 \mathrm{~V}$. As shown in Figure 5, obvious peaks can be seen from the ${ }^{51} \mathrm{~V}$ NMR spectrum when charging $\mathrm{Na}_{3} \mathrm{~V}\left(\mathrm{PO}_{4}\right)_{2}$ to $4.3 \mathrm{~V}$. Because standard NMR methods only detect $\mathrm{V}^{5+}$, which possesses zero localized $d$ electrons, the presence of $\mathrm{V}^{5+}$ in $\mathrm{Na}_{2-x} \mathrm{~V}\left(\mathrm{PO}_{4}\right)_{2}$ is therefore proved. As a comparison, there is only noise signal in the ${ }^{51} \mathrm{~V}$ ssNMR spectrum by charging $\mathrm{Na}_{3} \mathrm{~V}\left(\mathrm{PO}_{4}\right)_{2}$ to $3.8 \mathrm{~V}$ (i.e., $\left.\mathrm{Na}_{2} \mathrm{~V}\left(\mathrm{PO}_{4}\right)_{2}\right)$, indicating that the $\mathrm{V}^{5+}$ ion is absent. In fact, Kang et al. have confirmed that the oxidation state is +4 in $\mathrm{Na}_{2} \mathrm{~V}\left(\mathrm{PO}_{4}\right)_{2}$ through $\mathrm{V}$ K-edge XANES [37]. Consequently, $\mathrm{Na}_{3} \mathrm{~V}\left(\mathrm{PO}_{4}\right)_{2}$ is demonstrated to be a potential high energy density cathode $(657 \mathrm{Wh} / \mathrm{kg})$ with $\mathrm{V}^{3+} / \mathrm{V}^{4+} / \mathrm{V}^{5+}$ multielectron reactions, albeit it displays inferior reversibility and cyclic stability. The capacity degradation of $\mathrm{Na}_{3} \mathrm{~V}\left(\mathrm{PO}_{4}\right)_{2}$ is possibly caused by the gliding of $\mathrm{V}\left(\mathrm{PO}_{4}\right)_{2}$ slabs [6,7], large volume change [36,37], and collapsing of the framework [17] during Na deintercalation. These adverse effects commonly exist in layered transition metal oxide cathodes, which are mainly attributed to the local distortion caused by a drastic change of ion size and electrostatic repulsion between two slabs due to Na deintercalation [6,7]. It should be noted that although $\mathrm{Na}_{3} \mathrm{~V}\left(\mathrm{PO}_{4}\right)_{2}$ shows unsatisfactory electrochemical performance at present, this work would attract lots of research interests to $\mathrm{Na}_{3} \mathrm{~V}\left(\mathrm{PO}_{4}\right)_{2}$ due to its high theoretical energy density based on $\mathrm{V}^{3+} / \mathrm{V}^{4+} / \mathrm{V}^{5+}$ multielectron reactions. The theoretical energy density is expected to be realized by combining a better understanding of the working mechanism and further optimization of the material (e.g., a doping method which is frequently used for the layered transition metal cathodes [6,7]).

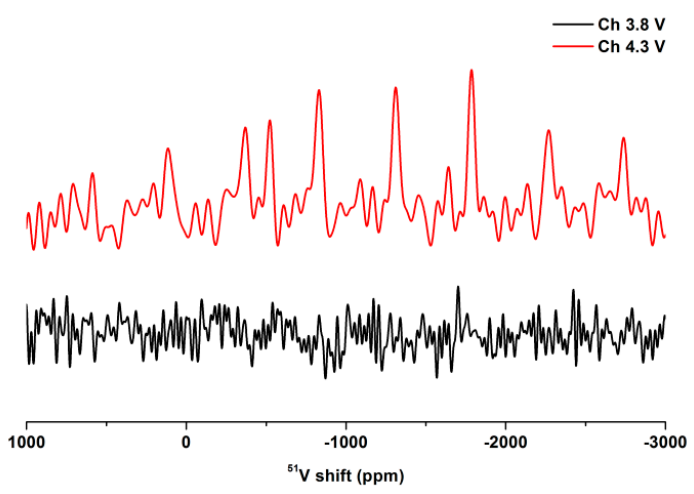

Figure 5. Ex situ ${ }^{51} \mathrm{~V}$ solid-state NMR (ssNMR) of $\mathrm{Na}_{3} \mathrm{~V}\left(\mathrm{PO}_{4}\right)_{2}$ charged to different voltages in the first cycle. 


\section{Discussion}

In summary, as a cathode material for SIBs, $\mathrm{Na}_{3} \mathrm{~V}\left(\mathrm{PO}_{4}\right)_{2}$ could reversibility uptake $1 \mathrm{Na}$ at $\sim 3.4 \mathrm{~V}$ with a $\mathrm{V}^{3+} / \mathrm{V}^{4+}$ reaction. Additional $\mathrm{Na}$ could be extracted at around $4.0 \mathrm{~V}$ when extending the upper cut-off voltage limit to $4.3 \mathrm{~V} .{ }^{51} \mathrm{~V}$ ssNMR further revealed that the high voltage plateau could be ascribed to $\mathrm{V}^{4+} / \mathrm{V}^{5+}$ reactions. Consequently, $\mathrm{Na}_{3} \mathrm{~V}\left(\mathrm{PO}_{4}\right)_{2}$ can potentially deliver two electrons through $\mathrm{V}^{3+} / \mathrm{V}^{4+} / \mathrm{V}^{5+}$ reactions, thus resulting in a high theoretical energy density of $657 \mathrm{Wh} / \mathrm{kg}$, which outperforms most of the known polyanion and layered oxides. Albeit the reversibility and the observed energy density are still far from the theoretical value, we believe this material is worth further investigation due to its potential high energy density.

\section{Materials and Methods}

$\mathrm{Na}_{3} \mathrm{~V}\left(\mathrm{PO}_{4}\right)_{2} / \mathrm{C}$ was synthesized via a solid-state method. In a typical synthesis, the starting materials were $0.585 \mathrm{~g} \mathrm{NH}_{4} \mathrm{VO}_{3}$ (5.00 mmol, Aladdin Reagent Co., Ltd., Shanghai, China), $1.321 \mathrm{~g}$ $\left(\mathrm{NH}_{4}\right)_{2} \mathrm{HPO}_{4}\left(10.00 \mathrm{mmol}\right.$, Sinopharm Chemical Reagent Co., Ltd., Shanghai, China), $0.874 \mathrm{~g} \mathrm{Na}_{2} \mathrm{CO}_{3}$ (8.25 mmol, corresponding to $10 \%$ excess of $\mathrm{Na}$, Sinopharm Chemical Reagent Co., Ltd., Shanghai, China), and $0.2 \mathrm{~g}$ acetylene black (AB, Sinopharm Chemical Reagent Co., Ltd., Shanghai, China), which served as the redundant and carbon source. All of the starting materials were mixed and then ball milled for $5 \mathrm{~h}$ at a speed of $400 \mathrm{rpm}$. The mixture was pressed into a pellet and then heated in a tube furnace in an Ar atmosphere at $350{ }^{\circ} \mathrm{C}$ for $6 \mathrm{~h}$, after which the intermediate product was re-crushed and ball milled for $10 \mathrm{~h}$ and pressed into a pellet again. The final product was obtained by calcining the pellet in the tube furnace at 700 or $750{ }^{\circ} \mathrm{C}$ for $20 \mathrm{~h}$. Occasionally, the final product was washed by $0.5 \mathrm{M} \mathrm{HCl}, 0.1 \mathrm{M} \mathrm{NaOH}$, and deionized water successively in order to remove impurities.

XRD scans were carried out in a Rigaku Ultima IV powder X-ray diffractometer (Rigaku Corporation, Tokyo, Japan) using Cu K $\alpha$ radiation $(\lambda=1.5406 \AA$ ) operated at $40 \mathrm{kV}$ and $30 \mathrm{~mA}$ from $2 \theta=10-100^{\circ}$ at a scan speed of $2^{\circ} / \mathrm{min}$.

Time-of-fight (TOF) powder neutron diffraction data were collected using the VULCAN instrument from Spallation Neutron Sources (SNS), Oak Ridge National Laboratory (ORNL) [40]. Approximately $1.6 \mathrm{~g}$ of powder was filled into a vanadium sample can. An incident beam $(5 \mathrm{~mm} \times 12 \mathrm{~mm})$ of 0.7 to $3.5 \AA$ bandwidth, allowing $0.5 \sim 3.6 \AA$ d-space in the diffracted pattern of the $\pm 90^{\circ}$ detector banks, was selected using the double-disk choppers at a $20 \mathrm{~Hz}$ frequency. High-resolution mode was employed with $\Delta \mathrm{d} / \mathrm{d} \sim 0.25 \%$. The SNS was at nominal, $1100 \mathrm{KW}$, power [40]. Powder neutron diffraction data were collected in high resolution mode for a duration of $3 \mathrm{~h}$ and processed using VDRIVE software [41]. Combined Rietveld refinement of XRD and ND data were performed using a GSAS code with the EXPGUI interface [42,43].

The chemical composition of the sample was determined using an Agilent ICP-MS/MS 8800 (Agilent Technologies, Santa Clara, CA, United States). The charge valence of vanadium was measured by vanadium K-edge XANES, which was collected in transmission mode at room temperature, using ion chamber detectors at beamline BL14W1 of the Shanghai Synchrotron Radiation Facility (SSRF) and a $\mathrm{Si}(111)$ double-crystal monochromator. The data were collected over an energy range from $200 \mathrm{eV}$ below to $500 \mathrm{eV}$ above the $\mathrm{V}(5465 \mathrm{eV})$. The incident photon energy was calibrated using standard $\mathrm{V}$ metal foil. Processing and fitting of the XANES data were performed using Athena software (version 0.9.25) [44].

The ${ }^{51} \mathrm{~V}$ ssNMR spectra were acquired on a Bruker Avance III $400 \mathrm{MHz}$ NMR spectrometer (Bruker, Faellanden, Zurich, Switzerland) using $1.3 \mathrm{~mm}$ probehead at a spinning rate of $50 \mathrm{kHz}$. A recycle delay of $2 \mathrm{~s}$ and a $90^{\circ}$ pulse length of $2 \mu$ s were used for spin echo. The chemical shift of ${ }^{51} \mathrm{~V}$ was referenced to $\mathrm{V}_{2} \mathrm{O}_{5}$ powder (-610 ppm).

The active materials, acetylene black $\left(\mathrm{C}_{\mathrm{AB}}\right)$, and polyvinylidene fluoride (PVDF), were mixed in the weight ratio of 8:1:1 using $N$-methyl-2-pyrrolidone (NMP) as the solvent. The obtained slurry was coated onto an $\mathrm{Al}$ foil substrate and dried overnight in a vacuum oven at $120^{\circ} \mathrm{C}$. The loading and thickness of the active material are $\sim 3 \mathrm{mg} / \mathrm{cm}^{2}$ and $\sim 20 \mu \mathrm{m}$, respectively. Cells were assembled in an argon-filled glove box using $\mathrm{Na}$ metal foil as the counter electrode (and reference electrode 
for three electrode cells), and a glass fiber as the separator. The electrolyte was composed of a solution of $1 \mathrm{M} \mathrm{NaClO}_{4}$ in propylene carbonate (PC) and fluoroethylene carbonate (FEC) (98:2 by volume). Cyclic voltammetry (CV) was performed using T-shaped Swagelok three electrode cells at a scan rate of $0.05 \mathrm{mV} / \mathrm{s}$ over the voltage range of $2.5-3.8 \mathrm{~V}$ and $4.3 \mathrm{~V}$ at 30 or $45^{\circ} \mathrm{C}$ using a Versa STAT MV Multichannel potentiostat/galvanostat (Princeton Applied Research, Oak Ridge, TN, USA). Galvanostatic charge/discharge tests were performed using a coin cell at C/20 (i.e., $8.65 \mathrm{~mA} / \mathrm{g}$ ) in the voltage of 2.5-3.8 V and 2.5-4.3 V on a LAND CT-2001A (Wuhan, China) battery test system. QOCV was carried out by cycling the coin cell at $\mathrm{C} / 20$ for $30 \mathrm{~min}$, followed by a $5 \mathrm{~h}$ relaxation between steps. For ex situ ${ }^{51} \mathrm{~V}$ ssNMR measurements, each cell was stopped at 3.8 and $4.3 \mathrm{~V}$ during the first charging and disassembled in an Ar-filled glove box. The electrodes were washed by PC and then dimethyl carbonate (DMC) for three times. The electrode materials were scraped carefully from the $\mathrm{Al}$ current collector and sealed in the probehead in the glove box.

Supplementary Materials: The following are available online, Table S1: V- and Mn-based polyanionic cathodes with multielectron reactions, Table S2: Atomic parameters for $\mathrm{Na}_{3} \mathrm{~V}\left(\mathrm{PO}_{4}\right)_{2}$, Figure S1: Crystal structure of $\mathrm{Na}_{3} \mathrm{~V}\left(\mathrm{PO}_{4}\right)_{2}$, Figure S2: SEM image of $\mathrm{Na}_{3} \mathrm{~V}_{(}\left(\mathrm{PO}_{4}\right)_{2}$, Figure S3: XANES spectra of $\mathrm{Na}_{3} \mathrm{~V}\left(\mathrm{PO}_{4}\right)_{2}$ and $\mathrm{Na}_{3} \mathrm{VCr}\left(\mathrm{PO}_{4}\right)_{3}$, Figure S4: QOCV curve of the $\mathrm{Na}_{3} \mathrm{~V}\left(\mathrm{PO}_{4}\right)_{2}$ cathode in the voltage range of 2.5-3.8 V, Figure S5: Cycling performance of the $\mathrm{Na}_{3} \mathrm{~V}\left(\mathrm{PO}_{4}\right)_{2}$ cathode.

Author Contributions: Conceptualization, R.L. and Y.Y.; methodology, R.L., Z.L., Y.X., W.Z., Y.C., and K.A.; writing-original draft preparation, R.L.; writing—review and editing, H.L.; supervision, Y.Y. All authors have read and agreed to the published version of the manuscript.

Funding: This work is financially supported by National Key Research and Development Program of China (grant no. 2018YFB0905400,2016YFB0901500) and the National Natural Science Foundation of China (grant no. 21233004, 21428303, 21621091)

Acknowledgments: The authors thank the staff at beamline BL14W1 in the Shanghai Synchrotron Radiation Facility (SSRF) (Shanghai, China). Neutron diffraction work was carried out at the Spallation Neutron Source (SNS), which is the U.S. Department of Energy (DOE) user facility at the Oak Ridge National Laboratory, sponsored by the Scientific User Facilities Division, Office of Basic Energy Sciences. This manuscript has been authored by UT-Battelle, LLC under Contract No. DE-AC05-00OR22725 with the U.S. Department of Energy. The United States Government retains and the publisher, by accepting the article for publication, acknowledges that the United States Government retains a non-exclusive, paid-up, irrevocable, worldwide license to publish or reproduce the published form of this manuscript, or allow others to do so, for United States Government purposes. The Department of Energy will provide public access to these results of federally sponsored research in accordance with the DOE Public Access Plan (http://energy.gov/downloads/doe-public-access-plan).

Conflicts of Interest: The authors declare no conflict of interest.

\section{References}

1. Li, Y.; Lu, Y.; Zhao, C.; Hu, Y.-S.; Titirici, M.-M.; Li, H.; Huang, X.; Chen, L. Recent advances of electrode materials for low-cost sodium-ion batteries towards practical application for grid energy storage. Energy Storage Mater. 2017, 7, 130-151. [CrossRef]

2. You, Y.; Manthiram, A. Progress in High-Voltage Cathode Materials for Rechargeable Sodium-Ion Batteries. Adv. Energy Mater. 2018, 8, 1701785. [CrossRef]

3. Pu, X.; Wang, H.; Zhao, D.; Yang, H.; Ai, X.; Cao, S.; Chen, Z.; Cao, Y. Recent Progress in Rechargeable Sodium-Ion Batteries: toward High-Power Applications. Small 2019, 15, 1805427. [CrossRef] [PubMed]

4. Huang, Y.Y.; Zheng, Y.H.; Li, X.; Adams, F.; Luo, W.; Huang, Y.H.; Hu, L.B. Electrode Materials of Sodium-Ion Batteries toward Practical Application. ACS Energy Lett. 2018, 3, 1604-1612. [CrossRef]

5. Liu, Q.; Hu, Z.; Chen, M.; Zou, C.; Jin, H.; Wang, S.; Chou, S.-L.; Dou, S.-X. Recent Progress of Layered Transition Metal Oxide Cathodes for Sodium-Ion Batteries. Small 2019, 15, 1805381. [CrossRef] [PubMed]

6. Zheng, S.Y.; Zhong, G.M.; McDonald, M.J.; Gong, Z.L.; Liu, R.; Wen, W.; Yang, C.; Yang, Y. Exploring the working mechanism of $\mathrm{Li}^{+}$in O3-type $\mathrm{NaLi}_{0.1} \mathrm{Ni}_{0.35} \mathrm{Mn}_{0.55} \mathrm{O}_{2}$ cathode materials for rechargeable Na-ion batteries. J. Mater. Chem. A 2016, 4, 9054-9062. [CrossRef] 
7. Wu, X.H.; Xu, G.L.; Zhong, G.M.; Gong, Z.L.; McDonald, M.J.; Zheng, S.Y.; Fu, R.Q.; Chen, Z.H.; Amine, K.; Yang, Y. Insights into the Effects of Zinc Doping on Structural Phase Transition of P2-Type Sodium Nickel Manganese Oxide Cathodes for High-Energy Sodium Ion Batteries. ACS Appl. Mater. Interfaces 2016, 8, 22227-22237. [CrossRef]

8. Masquelier, C.; Croguennec, L. Polyanionic (Phosphates, Silicates, Sulfates) Frameworks as Electrode Materials for Rechargeable Li (or Na) Batteries. Chem. Rev. 2013, 113, 6552-6591. [CrossRef]

9. Ni, Q.; Bai, Y.; Wu, F.; Wu, C. Polyanion-Type Electrode Materials for Sodium-Ion Batteries. Adv. Sci. 2017, 4, 1600275. [CrossRef]

10. Barpanda, P.; Lander, L.; Nishimura, S.; Yamada, A. Polyanionic Insertion Materials for Sodium-Ion Batteries. Adv. Energy Mater. 2018, 8, 1703055. [CrossRef]

11. Liu, R.; Liu, H.; Sheng, T.; Zheng, S.; Zhong, G.; Zheng, G.; Liang, Z.; Ortiz, G.F.; Zhao, W.; Mi, J.; et al. Novel 3.9 V Layered $\mathrm{Na}_{3} \mathrm{~V}_{3}\left(\mathrm{PO}_{4}\right)_{4}$ Cathode Material for Sodium Ion Batteries. ACS Appl. Energy Mater. 2018, 1, 3603-3606. [CrossRef]

12. Hurlbutt, K.; Wheeler, S.; Capone, I.; Pasta, M. Prussian Blue Analogs as Battery Materials. Joule 2018, 2, 1950-1960. [CrossRef]

13. You, Y.; Wu, X.L.; Yin, Y.X.; Guo, Y.G. High-quality Prussian blue crystals as superior cathode materials for room-temperature sodium-ion batteries. Energy Environ. Sci. 2014, 7, 1643-1647. [CrossRef]

14. You, Y.; Yao, H.R.; Xin, S.; Yin, Y.X.; Zuo, T.T.; Yang, C.P.; Guo, Y.G.; Cui, Y.; Wan, L.J.; Goodenough, J.B. Subzero-Temperature Cathode for a Sodium-Ion Battery. Adv. Mater. 2016, 28, 7243. [CrossRef] [PubMed]

15. Choi, J.W.; Aurbach, D. Promise and reality of post-lithium-ion batteries with high energy densities. Nat. Rev. Mater. 2016, 1, 16013. [CrossRef]

16. Liu, H.D.; Xu, J.; Ma, C.Z.; Meng, Y.S. A new O3-type layered oxide cathode with high energy/power density for rechargeable Na batteries. Chem. Commun. 2015, 51, 4693-4696. [CrossRef]

17. Liu, R.; Liang, Z.; Gong, Z.; Yang, Y. Research Progress in Multielectron Reactions in Polyanionic Materials for Sodium-Ion Batteries. Small Methods 2018, 3, 1800221. [CrossRef]

18. de Boisse, B.M.; Ming, J.; Nishimura, S.I.; Yamada, A. Alkaline Excess Strategy to NASICON-Type Compounds towards Higher-Capacity Battery Electrodes. J. Electrochem. Soc. 2016, 163, A1469-A1473. [CrossRef]

19. Zakharkin, M.V.; Drozhzhin, O.A.; Tereshchenko, I.V.; Chernyshov, D.; Abakumov, A.M.; Antipov, E.V.; Stevenson, K.J. Enhancing $\mathrm{Na}^{+}$Extraction Limit through High Voltage Activation of the NASICON-Type $\mathrm{Na}_{4} \mathrm{MnV}\left(\mathrm{PO}_{4}\right)_{3}$ Cathode. ACS Appl. Energy Mater. 2018, 1, 5842-5846. [CrossRef]

20. Chen, F.; Kovrugin, V.M.; David, R.; Mentré, O.; Fauth, F.; Chotard, J.N.; Masquelier, C. A NASICON-Type Positive Electrode for Na Batteries with High Energy Density: $\mathrm{Na}_{4} \mathrm{MnV}\left(\mathrm{PO}_{4}\right)_{3}$. Small Methods 2018, 2, 1800218. [CrossRef]

21. Yan, G.C.; Mariyappan, S.; Rousse, G.; Jacquet, Q.; Deschamps, M.; David, R.; Mirvaux, B.; Freeland, J.W.; Tarascon, J.M. Higher energy and safer sodium ion batteries via an electrochemically made disordered $\mathrm{Na}_{3} \mathrm{~V}_{2}\left(\mathrm{PO}_{4}\right)_{2} \mathrm{~F}_{3}$ material. Nat. commun. 2019, 10, 585. [CrossRef] [PubMed]

22. Nguyen, L.H.B.; Broux, T.; Camacho, P.S.; Denux, D.; Bourgeois, L.; Belin, S.; Iadecola, A.; Fauth, F.; Carlier, D.; Olchowka, J.; et al. Stability in water and electrochemical properties of the $\mathrm{Na}_{3} \mathrm{~V}_{2}\left(\mathrm{PO}_{4}\right)_{2} \mathrm{~F}_{3}-\mathrm{Na}_{3}(\mathrm{VO})_{2}\left(\mathrm{PO}_{4}\right)_{2} \mathrm{~F}$ solid solution. Energy Storage Mater. 2019, 20, 324-334. [CrossRef]

23. Gao, H.C.; Li, Y.T.; Park, K.; Goodenough, J.B. Sodium Extraction from NASICON-Structured $\mathrm{Na}_{3} \mathrm{MnTi}_{(}\left(\mathrm{PO}_{4}\right)_{3}$ through Mn(III)/Mn(II) and Mn(IV)/Mn(III) Redox Couples. Chem. Mater. 2016, 28, 6553-6559. [CrossRef]

24. Gao, H.C.; Seymour, I.D.; Xin, S.; Xue, L.G.; Henkelman, G.; Goodenough, J.B. $\mathrm{Na}_{3} \mathrm{MnZr}_{2}\left(\mathrm{PO}_{4}\right)_{3}: \mathrm{A}$ High-Voltage Cathode for Sodium Batteries. J. Am. Chem. Soc. 2018, 140, 18192-18199. [CrossRef] [PubMed]

25. Liu, R.; Xu, G.L.; Li, Q.; Zheng, S.Y.; Zheng, G.R.; Gong, Z.L.; Li, Y.X.; Kruskop, E.; Fu, R.Q.; Chen, Z.H.; et al. Exploring Highly Reversible 1.5-Electron Reactions $\left(\mathrm{V}^{3+} / \mathrm{V}^{4+} / \mathrm{V}^{5+}\right)$ in $\mathrm{Na}_{3} \mathrm{VCr}\left(\mathrm{PO}_{4}\right)_{3}$ Cathode for Sodium-Ion Batteries. ACS Appl. Mater. Interfaces 2017, 9, 43632-43639. [CrossRef] [PubMed]

26. Lalere, F.; Seznec, V.; Courty, M.; David, R.; Chotard, J.N.; Masquelier, C. Improving the energy density of $\mathrm{Na}_{3} \mathrm{~V}_{2}\left(\mathrm{PO}_{4}\right)_{3}$-based positive electrodes through V/Al substitution. J. Mater. Chem. A 2015, 3, 16198-16205. [CrossRef]

27. You, Y.; Xin, S.; Asl, H.Y.; Li, W.; Wang, P.-F.; Guo, Y.-G.; Manthiram, A. Insights into the Improved High-Voltage Performance of Li-Incorporated Layered Oxide Cathodes for Sodium-Ion Batteries. Chem 2018, 4, 2124-2139. [CrossRef] 
28. Jian, Z.L.; Hu, Y.S.; Ji, X.L.; Chen, W. NASICON-Structured Materials for Energy Storage. Adv. Mater. 2017, 29, 1601925. [CrossRef]

29. Chen, S.Q.; Wu, C.; Shen, L.F.; Zhu, C.B.; Huang, Y.Y.; Xi, K.; Maier, J.; Yu, Y. Challenges and Perspectives for NASICON-Type Electrode Materials for Advanced Sodium-Ion Batteries. Adv. Mater. 2017, 29, 1700431. [CrossRef]

30. Yabuuchi, N.; Kajiyama, M.; Iwatate, J.; Nishikawa, H.; Hitomi, S.; Okuyama, R.; Usui, R.; Yamada, Y.; Komaba, S. P2-type $\mathrm{Na}_{x}\left[\mathrm{Fe}_{1 / 2} \mathrm{Mn}_{1 / 2}\right] \mathrm{O}_{2}$ made from earth-abundant elements for rechargeable Na batteries. Nat. Mater. 2012, 11, 512-517. [CrossRef]

31. Aragon, M.J.; Lavela, P.; Ortiz, G.F.; Tirado, J.L. Effect of Iron Substitution in the Electrochemical Performance of $\mathrm{Na}_{3} \mathrm{~V}_{2}\left(\mathrm{PO}_{4}\right)_{3}$ as Cathode for Na-Ion Batteries. J. Electrochem. Soc. 2015, 162, A3077-A3083. [CrossRef]

32. Aragon, M.J.; Lavela, P.; Alcantara, R.; Tirado, J.L. Effect of aluminum doping on carbon loaded $\mathrm{Na}_{3} \mathrm{~V}_{2}\left(\mathrm{PO}_{4}\right)_{3}$ as cathode material for sodium-ion batteries. Electrochim. Acta 2015, 180, 824-830. [CrossRef]

33. Aragon, M.J.; Lavela, P.; Ortiz, G.F.; Tirado, J.L. Benefits of Chromium Substitution in $\mathrm{Na}_{3} \mathrm{~V}_{2}\left(\mathrm{PO}_{4}\right)_{3}$ as a Potential Candidate for Sodium-Ion Batteries. Chemelectrochem 2015, 2, 995-1002. [CrossRef]

34. Liu, Z.; Hu, Y.-Y.; Dunstan, M.T.; Huo, H.; Hao, X.; Zou, H.; Zhong, G.; Yang, Y.; Grey, C.P. Local Structure and Dynamics in the $\mathrm{Na}$ Ion Battery Positive Electrode Material $\mathrm{Na}_{3} \mathrm{~V}_{2}\left(\mathrm{PO}_{4}\right)_{2} \mathrm{~F}_{3}$. Chem. Mater. 2014, 26, $2513-2521$. [CrossRef]

35. Broux, T.; Bamine, T.; Simonelli, L.; Stievano, L.; Fauth, F.; Menetrier, M.; Carlier, D.; Masquelier, C.; Croguennec, L. VIV Disproportionation Upon Sodium Extraction From $\mathrm{Na}_{3} \mathrm{~V}_{2}\left(\mathrm{PO}_{4}\right)_{2} \mathrm{~F}_{3}$ Observed by Operando X-ray Absorption Spectroscopy and Solid-State NMR. J. Phys. Chem. C 2017, 121, 4103-4111. [CrossRef]

36. Kovrugin, V.M.; David, R.; Chotard, J.-N.; Recham, N.; Masquelier, C. A High Voltage Cathode Material for Sodium Batteries: $\mathrm{Na}_{3} \mathrm{~V}\left(\mathrm{PO}_{4}\right)_{2}$. Inorg. Chem. 2018, 57, 8760-8768. [CrossRef]

37. Kim, J.; Yoon, G.; Kim, H.; Park, Y.U.; Kang, $\mathrm{K} . \mathrm{Na}_{3} \mathrm{~V}\left(\mathrm{PO}_{4}\right)_{2}$ : A New Layered-Type Cathode Material with High Water Stability and Power Capability for Na-Ion Batteries. Chem. Mater. 2018, 30, 3683-3689. [CrossRef]

38. Dupre, N.; Gaubicher, J.; Guyomard, D.; Grey, C.P. Li-7 and V-51 MAS NMR study of the electrochemical Behavior of $\mathrm{Li}_{1-x} \mathrm{~V}_{3} \mathrm{O}_{8}$. Chem. Mater. 2004, 16, 2725-2733. [CrossRef]

39. Sale, M.; Avdeev, M. 3DBVSMAPPER: a program for automatically generating bond-valence sum landscapes. J. Appl. Crystallogr. 2012, 45, 1054-1056. [CrossRef]

40. An, K.; Skorpenske, H.D.; Stoica, A.D.; Ma, D.; Wang, X.-L.; Cakmak, E. First In Situ Lattice Strains Measurements Under Load at VULCAN. Metall. Mater. Trans. A 2011, 42, 95-99. [CrossRef]

41. An, K.; Wang, X.L.; Stoica, A.D. Vulcan Data Reduction and Interactive Visualization Software. ORNL Rep. 2012, 621, 1 .

42. Toby, B.H. EXPGUI, a graphical user interface for GSAS. J. Appl. Crystallogr. 2001, 34, 210-213. [CrossRef]

43. Larson, A.C.; Dreele, R.B.V. General Structure Analysis System (GSAS); Los Alamos National Laboratory Report LAUR: Los Alamos, CA, USA, 2000; pp. 86-748.

44. Ravel, B.; Newville, M. ATHENA, ARTEMIS, HEPHAESTUS: data analysis for X-ray absorption spectroscopy using IFEFFIT. J. Synchrotron Radiat. 2005, 12, 537-541. [CrossRef] [PubMed]

Sample Availability: Samples of the compounds are available from the authors.

(C) 2020 by the authors. Licensee MDPI, Basel, Switzerland. This article is an open access article distributed under the terms and conditions of the Creative Commons Attribution (CC BY) license (http://creativecommons.org/licenses/by/4.0/). 